* Corresponding author

Phone +421556023156

E-mail address:jozefvarga@tuke.sk

(Jozef Varga, Ing.)

Article information

Article history: AMS-Volume15-No.4-00125-11

Received 05 April 2011

Accepted 18 May 2011

\section{Design of Humanoid's Lower Limbs Model and Phases of Walking}

\author{
Marek Sukop, Mikuláš Hajduk, Luboš Marko, Jozef Varga* \\ Department of Production Systems and Robotics, Nëmcovej 32, 04200 Košice, Slovak Republic
}

\section{BIOGRAPHICAL NOTES}

Marek Sukop, Ing. PhD., born in Ocotber 2, 1976 in Kosice. He graduates in 2001 at the Technical University of Košice, Faculty of Mechanical Engineering, Department of Production Systems and Robotics with title Ing. In March 2009 he completed a doctorate. This time operates at a Technical university of Košice, Faculty of Mechanical Engineering, Department of Production Systems and Robotics as an Assistant Professor. It addresses the issue of applied research in the field of robosoccer with multiagent system applications.

Mikuláš Hajduk, prof. Ing. PhD, born in December 12, 1950, Malé Ozorovce. He graduates as professor in 1999 at Technical University of Košice in the filed of "production systems with industrial robots and manipulators". Nowadays he is the head at department of production systems and robotics and also an authorized person for robotic and production techniques. He is chairman and also member of board of state examiners. His scientific and research work focuses on the field of research and development of production systems and robotics. An accent is put on the issue of designing and maintenance of automatic robotic systems based on method implementation of computer intelligence.

Ĺuboš Marko, Ing. born in September 28, 1983 in Snina. He graduates in 2008 at the Technical University of Košice, Faculty of Mechanical Engineering, Department of Production Systems and Robotics with title Ing. This time operates at a Technical university of Košice, Faculty of Mechanical Engineering, Department of Production Systems and Robotics as an external PhD. student. Currently he works on the field of design and research by control systems with reconfigurable robots an computer modeling. Jozef Varga, Ing. born in January 28, 1986 in Trebišov. He graduates in 2010 at the Technical University of Košice, Faculty of Mechanical Engineering, Department of Production Systems and Robotics with title Ing. This time operates at a Technical university of Košice, Faculty of Mechanical Engineering, Department of Production Systems and Robotics as an internal PhD. student. Currently he works on the field of design of robotic systems and all it's components.

\section{KEYWORDS}

Humanoid, Robosoccer

\section{ABSTRACT}

This paper describes basic principles of the kinematic structure design for two - leg walking robots. The article deals with the design of walking phases detailed, which is described in sagital and frontal plane so that movement of the centre of gravity was outside the support polygon and also offers the model of walk for the concrete construction of the two - leg walking robot. This article is the result of research activities of our department in humanoid robotics. 


\section{Introduction}

In recent years come to the forefront the humanoid robots. The aim of the humanoid robotics is to approximate a bipedal principle of human walk. At our workplace, at The Department of Production Systems and Robotics deals with the small humanoid robot intended for robosoccer. The fundamental phenomenon of the robot's design is the solution of walking and stability securing.

Versatility and terrain adaptability is limited up to certain level due to the complexity of the walking principle and the control of robot movement alone. This paper deals with the particular solution of the principles problem and design of the mathematical model of walking of the designed two-leg walking robot [11].

\section{The principle of human walking}

When designing the structure of walk for bipedal walking robot constructed according to human as a model, it is necessary to choose the type of robot's walk and to define the fact up to which level we wish to imitate the human walk [4]. There is necessary to take into consideration the dynamic body stability of the human being using by walking. That means that in any phases of movement the centre of body gravity doesn't appear the bearing surface. Dynamic stability uses the potentiality of inertial body strength and their parts so to avoid the overturning into uncontrolled position (falling). Used are the principles of counterbalance's transmission and affect of inertial moments, for example the arms swing contrary with the opposite leg. Human being uses by the movement the mammals' posture which is characteristic in legs holding and motion in sagittal plane Fig. 1 square with longitudinal body axis. The legs of mammals have a pendulum motion, what achieve to reach the high speeding with low energy consumption for the movement. The animals with mammal's posture are able to move by walking, fast walking, running and jumping [9]. All the movements operated by human being during the motion are complicated. These movements consist of motion of individual body parts. These body parts are designated as the locomotive segment. In Fig. 1 are depicted the locomotive segments of human being, which are able to applied just for our walking humanoid robot.

\section{Design of humanoid's lower extremities model}

The design of walking structure for the robot with twelve-grade movement freedom of lower extremities Fig. 2 and Fig.3 is shown at the picture Fig. 4. It is a stationary steady way of walking, where in every moment of system's movement the robot's centre of gravity will be above the bearing surface of foot.

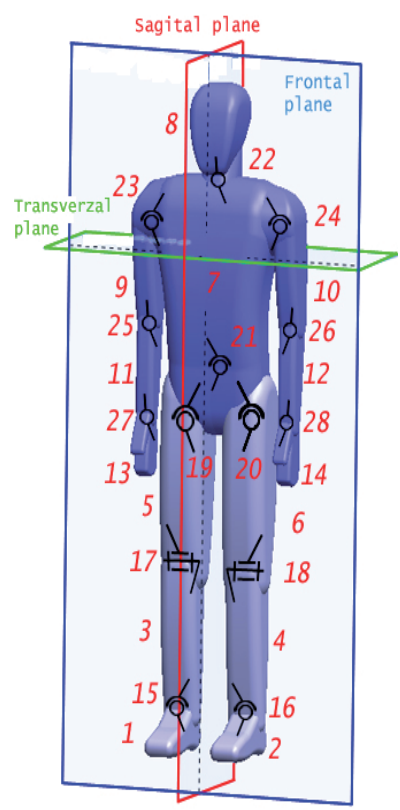

\begin{tabular}{|l|l|}
\hline LOCOMOTIVE SEGMENTS & JOINTS \\
\hline 1 - Foot of right leg & 15 - Ankle joint of right leg with $3^{\circ}$ movement freedom \\
\hline 2 - Foot of left leg & 16 - Ankle joint of left leg- $3^{\circ}$ movement freedom \\
\hline 3 - Shank of right leg & $17-$ Knee joint of right leg $-1^{\circ}$ movement freedom \\
\hline $4-$ Shank of left leg & $18-$ Knee joint of left leg with $1^{\circ}$ movement freedom \\
\hline $5-$ Thigh of right leg & $19-$ Hip joint of right leg with $3^{\circ}$ movement freedom \\
\hline $6-$ Thigh of left leg & $20-$ Hip joint of left leg with $3^{\circ}$ movement freedom \\
\hline $7-$ Trunk & $21-$ Movement of trunk with $3^{\circ}$ movement freedom \\
\hline $8-$ Head & $22-$ Movements of neck with $2^{\circ}$ movement freedom \\
\hline $9-$ Arm of right upper extremities & $\begin{array}{l}23-\text { Shoulder joint of right upper extremities with } 3^{\circ} \text { movement } \\
\text { freedom }\end{array}$ \\
\hline $10-$ Arm of left upper extremities & $\begin{array}{l}24-\text { Shoulder joint of left upper extremities with } 3^{\circ} \text { movement } \\
\text { freedom }\end{array}$ \\
\hline $11-$ Forearm of right upper extremities & $\begin{array}{l}25-\text { Elbow joint of right upper extremities with } 2^{\circ} \text { movement } \\
\text { freedom }\end{array}$ \\
\hline $12-$ Forearm of left upper extremities & $\begin{array}{l}26-\text { Elbow joint of left upper extremities with } 2^{\circ} \text { movement } \\
\text { freedom }\end{array}$ \\
\hline $13-$ Right hand & $27-$ Carpal joint of right hand with $2^{\circ}$ movement freedom \\
\hline
\end{tabular}

Fig. 1: Coordinate system and basic locomotive segments of human body. 
$a_{R^{\prime}} a_{1}, \beta_{R^{\prime}} \beta_{1}$ - angles of movement of the legs to the side; $\delta, \varphi, \lambda$ - angles when moving to the front, $\mathrm{k}$ - lenght step

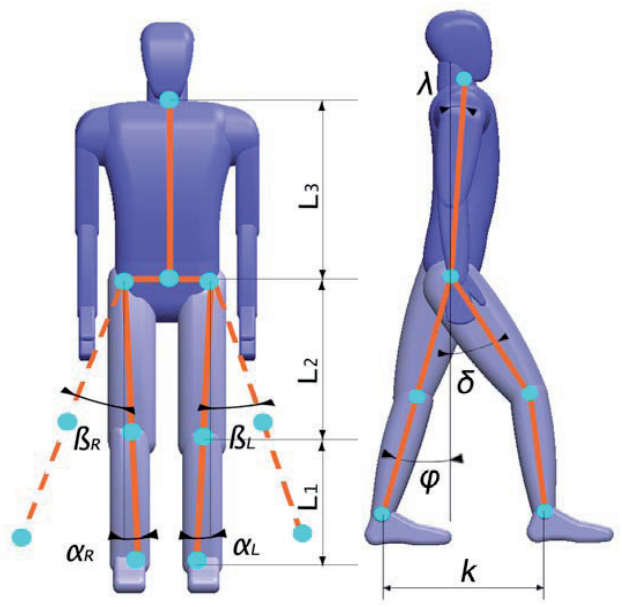

Fig. 2: Kinematic scheme of human for our designed robot.
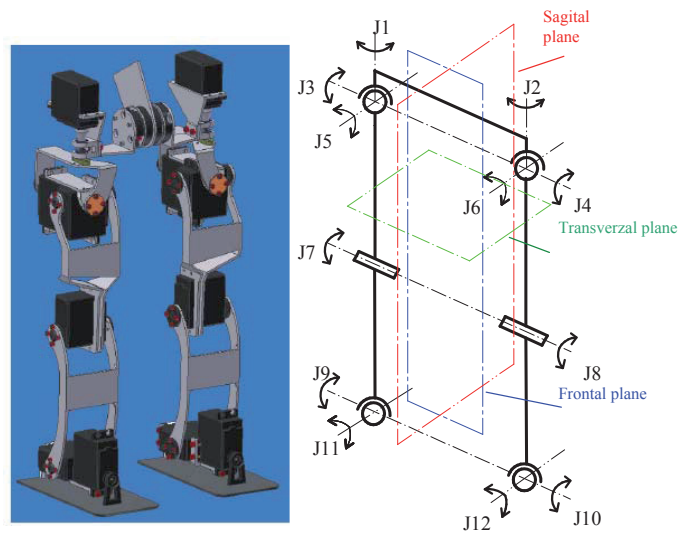

Fig. 3: 3D model and kinematic scheme of designed robot. Legenda: J1 - J12 - grades of robot's movement freedom
This modified walking has significantly smaller claim to control and mathematical depiction [2]. The walk has in this design firmly determined step's parameters, which are during the walking unchangeable. The step cycle is divided into 13 phases. In individual phases of robot's step the legs occur in bearing or in transferable phases, in which they change their position in space [7]. The individual end parts and knots are in motion in elliptical, circular and linear trajectories, which are bound in motion of kinematic structure's end point.

\section{Mathematical calculation of the robot's trajectory - phase No.3}

To calculate the individual robot movements within the space applied have been the calculations using the vector method of the inversion $\mathrm{ki}$ nematics [3]. Known are the parameters of the end element trajectories of the kinematic chain and applying the goniometrical functions and cosine theorem calculated can be the angular displacement of the individual robot joints. Application of the vector method calculation of the angular coordinates significantly simplified the overall calculations of the robot movements and the drives control as well. To illustrate the calculation was chosen phase No. 3 set off by left leg, because in this phase is showed the motion trajectory of robot's leg.

The step length used in the calculation is $k=240$ $\mathrm{mm}$. During the transfer phases of legs the ankle with the foot move parallel with the support along ellipse with the shorter axis $30 \mathrm{~mm}$ long, and therefore the step height is $v=30 \mathrm{~mm}$ [6]. The length of the thighbone is $\mathrm{a}=110 \mathrm{~mm}$, length of calf bone

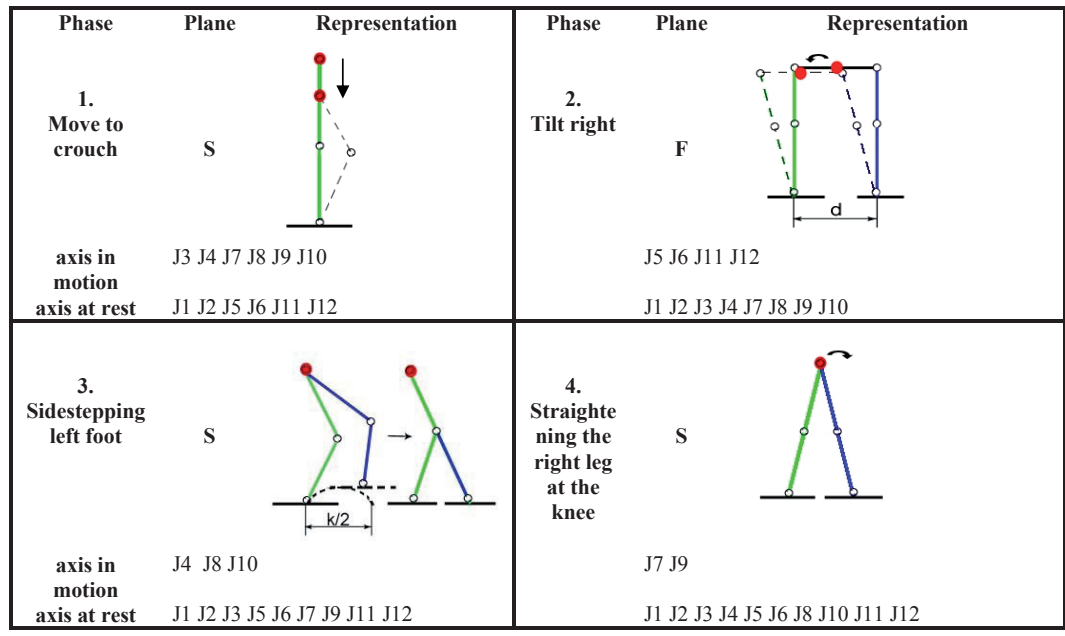




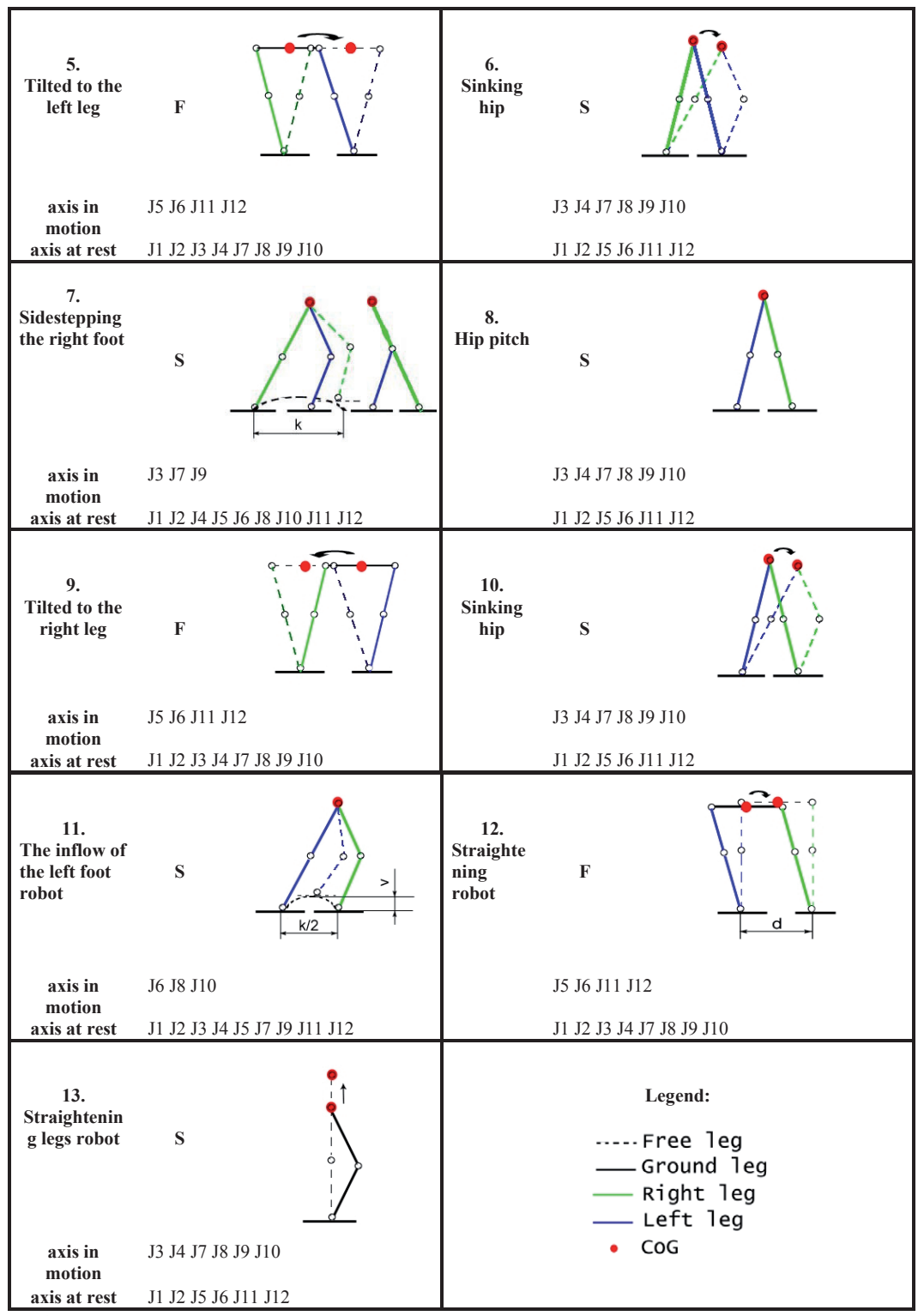

Fig. 4: Phases of step of modified robot walking.

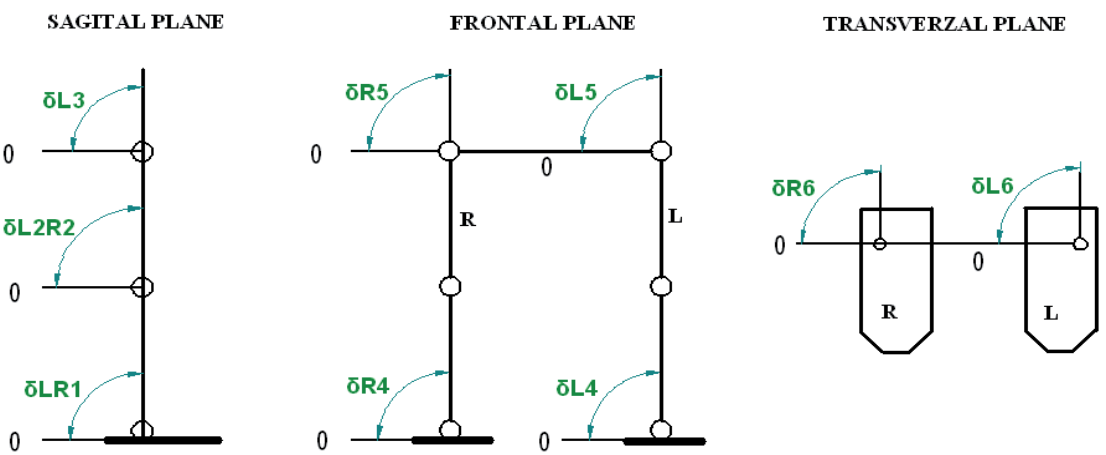

Fig. 5: Marking and orientation of calculation's angles of individual joints and the basic extent of robot. $\delta R$ - angles of motors' slewing in the right foot; angles of motors' slewing in the left foot 


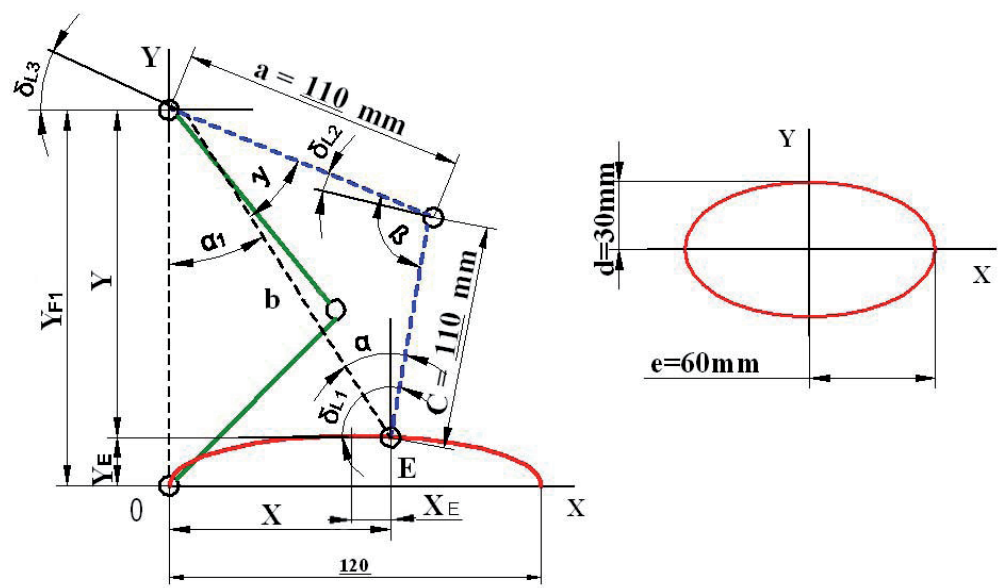

Fig. 6: Graphical demonstration of the movements in phase No. 3 and description of the trajectory parameters.

is $\mathrm{c}=11 \mathrm{~mm}$ and distance of the hip joint is $\mathrm{p}=$ $115 \mathrm{~mm}$. the designation of the calculation angles needed for the drives movement and basic dimensions of the kinematic structure are given in Fig. 5.

Phase No. 3 is step out with robot's left leg by the half step length $\mathrm{k} / 2=120 \mathrm{~mm}$, Fig. 5 . As the trajectory selected was the ellipse with the parameters given in Fig. 6. The controlling parameter for the calculation of the angle co-ordinates is the value $X E=(-60 /+60)$.Values $d$ and $e$ are the constants given by the ellipse dimensions [5]. Value a represents the length of the thighbone and value $\mathrm{c}$ is the length of the shank bone. Value YF1 is the last value of the co-ordinate $Y$ in phase No. 1.

From equation follow [8]:

$Y E=d * \sqrt{1-\left(\frac{X E}{e}\right)^{2}}$,

$X E=(-60 /+60)$

- For the co-ordinate of the ankle holds: $Y=Y F 1$ $Y E ; X=60+X E$

- for the created triangle with sides $X, Y, Z$ holds:

$b=\sqrt{Y^{2}+X^{2}}$

- from cosine theorem for the angles $\alpha, \beta, \gamma$ holds:

$$
\begin{aligned}
& \alpha=\arccos \left(\frac{b^{2}+c^{2}-a^{2}}{2 * b^{*} c}\right) \\
& \beta=\arccos \left(\frac{a^{2}+c^{2}-b^{2}}{2 * a * c}\right)
\end{aligned}
$$

$\gamma=\arccos \left(\frac{a^{2}+b^{2}-c^{2}}{2 * a * b}\right)$

- for the auxiliary angle a 1 holds:

$\alpha 1=\arccos \frac{Y}{b}$

- for the angles of the drives rotation hold:

$\delta L 1=90+\alpha-\alpha 1$

$\delta L 2=\beta-90$

$\delta L 3=90-\gamma-\alpha 1$

\section{Conclusion}

The aim of this paper was to describe the principle of the locomotive apparatus based on the human biology, design of the appropriate model of walking and its mathematical description. This walk is solved as the statically stabile in each instant of movement [10]. Designed system of robot walking provides the sufficient stability in its movement by the centre of gravity transfer above the individual supporting areas of feet. After detailed analysis of walking system's acting with designed walk's type we will to develop the new walk's types with respect to optimise and to keep the stability of two-leg robot's step.

\section{Acknowledge}

This contribution is the result of the project implementation: Komplexný modulárny robotický systém strednej kategórie s vyššou inteligenciou (STIMULY Req00169-0001) supported by the Research \& Development Operational Program funded by the ERDF. 


\section{References}

[1] [ČIRIP, M, HAJDUK, M., SUKOP, M.: Structural design of walking and mathematical model of humanoid robot MC 01, FIRA 2010 Bangalore, India, September 15 - 17, 2010 Proceedings, ISSN 1865 - 0929, ISBN - 10 3-642-15809-9, Springer Berlin Heidelberg New York 2010

[2] NEMEC, M.: Návrh bipedálneho kráčajúceho podvozku servisného robota, doktorandská dizertačná práca, KVTaR, SjF TUKE, Košice 2005

[3] ČIRIP, M; HAJDUK, M.: Návrh stabilizácie a matematických modelov kráčania humanoidných robotov, Košice, 2010

[4] HAJDUK, M.; MARKO, Ĺ:: Prístupy k navrhovaniu a riadenia exoskelotonu : písomná práca k dizertačnej skúške, Košice, 2010. - 47 s. :. - ISBN (brož.)

[5] JONG HWAN KIM; PRAHLAD, V.: Trends in Intelligent robotics: 13th FIRA Robot World Congress, FIRA 2010 Bangalore, India, September 15 - 17, 2010 Proceedings, ISSN 1865 0929, ISBN - 10 3-642-15809-9, Springer Berlin Heidelberg New York 2010
[6] DANIJELA RISTIĆ: RoboWalker Mobile Robot - Assisted Gait Rehabilitation System, Durrant 2010

[7] ŠIMŠÍK, D., GALAJDOVÁ, A., DOLNÁ, Z.: Variability of Gait in Different Daily Situations, IN: Acta Mechanica Slovaca, volume 14 No. 1/2010

[8] ŽIVČÁK, J: Scientific-Research Base of the Department of Biomechanical Engineering, Automation and Measurement at the Faculty of Mechanical Engineering, IN: Acta Mechanica Slovaca, volume 14 No. 2/2010

[9] GMITERKO, A, VIRGALA, I, VACKOVÁ, M.: Dynamic Analysis of the Two-Mass System to Imitate Rectilinear Motion of a Snake, IN: Acta Mechanica Slovaca, volume 14 No.2/2010

[10] TREBUŇA, F, JADLOVSKÝ, J, FRANKOVSKÝ, P, BAKŠIOVÁ, Z, KOSTELNÍKOVÁ, A.: Further Possibilities of Using PhotoStress for Separation of Principal Normal Stresses, IN: Acta Mechanica Slovaca, volume 14 No. 2/2010

[11] GMITERKO, A, KELEMEN, M, KELEMENOVÁ, T, MIKOVÁ, L'.: Adaptive Mechatronic Locomotion System, IN: Acta Mechanica Sloaca, volume 14 No. 2/2010

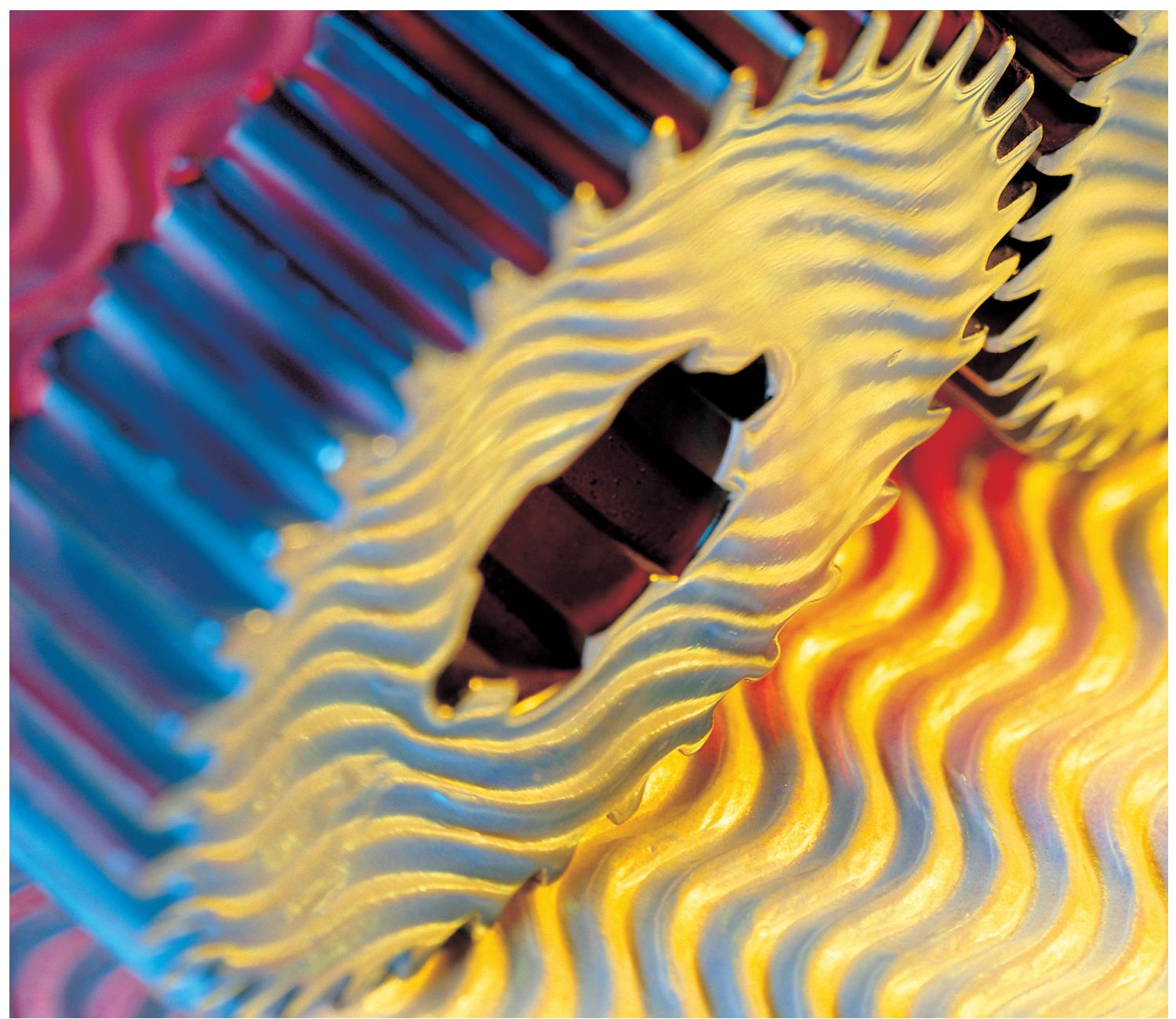

